\title{
Airborne measurements of $\mathrm{NO}_{y}$ and impact of this trace gas on atmospheric chemistry
}

\author{
P.E. Perros and T. Marion
}

Laboratoire Interuniversitaire des Systèmes Atmosphériques, Universités Paris 12 et 7, 61 avenue du Général de Gaulle, 94010 Créteil Cedex, France

\begin{abstract}
Nitrogen compounds play a key role in the ozone production processes. The airborne measurement of individual species is difficult compared to their global measurement. This can be done by the conversion of all the species $\left(\mathrm{NO}_{y}\right)$ in NO followed by a subsequent analysis by chemiluminescence. Laboratory tests allow us to determine the main characteristics of such conversion. $\mathrm{NO}_{y}$ measurements associated with $\mathrm{NO}_{x}$ concentrations allow a quantitative and qualitative study of ozone production processes. In particular it is possible to determine the ozone production potential of an air mass, the ozone production efficiency and to specify the chemical regimes.
\end{abstract}

ne of the most preoccupying environmental problems is the increasing levels of background tropospheric ozone. This level has multiplied 5-fold since the end of the last century [1]. The evolution of the oxidizing capacity of the atmosphere manifests itself at different spatial levels. On the regional level maximum amounts of oxidizing pollution (ozone in particular) are frequently observed during anticyclonic conditions (weak dispersion, strong sunlight) in particular in a variety of urban and industrial zones. This increase of ozone content and it's associated photooxidants has a notable health impact. On a global scale, the increase in tropospheric ozone may significantly contribute (approximately $15-20 \%$ ) to the greenhouse effect.

These adverse effects are discussed in a recent report from the French Academy of Science [2].

The ozone production processes are now rather wellknown. The production of photooxidants in the troposphere is the result of oxidation (in the gaseous phase) of volatile organic compounds (VOC) in the presence of the nitrogen oxides, $\mathrm{NO}$ and $\mathrm{NO}_{2}\left(\mathrm{NO}_{x}\right)$. The nitrogen oxides play a key role. As a result, according to their concentrations, they conduct the branching ratios between competitive reactions. In this manner, they govern the intensity of the production and possible destruction of the tropospheric ozone. The princi-

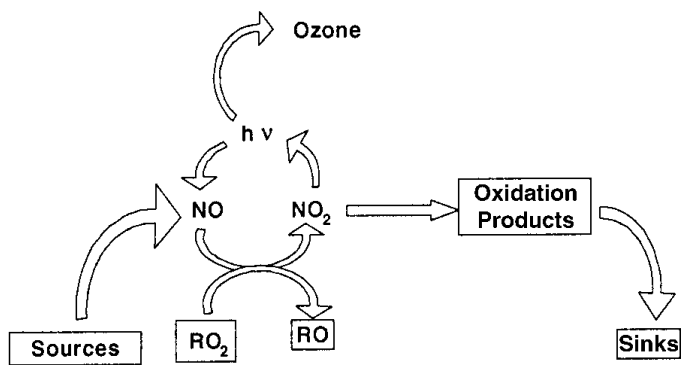

Figure 1. Simplified mechanism for tropospheric ozone production.

ple mechanism of this oxidation chain are presented in figure 1 .

The nitrogen compounds emitted in the atmosphere are essentially in the form of NO. This compound is rapidly oxidized into $\mathrm{NO}_{2}$ principally by the radical $\mathrm{RO}_{2}$ produced at the time of hydrocarbon oxidation by the $\mathrm{OH}$ radical. Photolysis of $\mathrm{NO}_{2}$ produces an ozone molecule and NO molecule which can again be oxidized. $\mathrm{NO}_{2}$ can also be converted to other oxidation products $\left(\mathrm{PAN}, \mathrm{HNO}_{3}\right.$, organic nitrates...) known as $\mathrm{NO}_{z}$ and leave the photochemical cycle of ozone production. The question is to know how many times this cycle will be carried out, producing at each cycle an ozone molecule, before the $\mathrm{NO}_{2}$ disappears in the form of $\mathrm{NO}_{z}$.

The collectivity of nitrogen compounds is known as $\mathrm{NO}_{y}$. It corresponds to the sum of $\mathrm{NO}_{x}+\mathrm{NO}_{z}$. The evolution of ozone production depends therefore on our knowledge of the nitrogen compounds distribution in the atmosphere. Only an airborne measurement allows us to study the spatial distribution (horizontal and vertical) of ozone and it's precursors.

\section{Measurement of $\mathrm{NO}_{y}$}

The amount of individual constituents of $\mathrm{NO}_{y}$ is difficult to assess especially using airborne methods of measurement. However, their global measurement can be easily obtained through the conversion in $\mathrm{NO}$ of it's different compounds 
following the measurement of NO formed by chemiluminescence. There exists two principle techniques employed since 1985 for converting reactive nitrogen oxides.

\section{Conversion on molybdenum (graphite) surface}

The air flow in a glass cartridge heated to $400{ }^{\circ} \mathrm{C}$ and filled with molybdenum chips allows a catalytic conversion of atmospheric nitrogen compounds. We obtain, as a result, the quantitative reduction of $\mathrm{NO}_{2}, \mathrm{NO}_{3}, \mathrm{HNO}_{3}, \mathrm{~N}_{2} \mathrm{O}_{5}, \mathrm{PAN}$ (90\%), as well as those of other organic nitrogen compounds more complex $\left(\mathrm{CH}_{3} \mathrm{ONO}_{2}, \mathrm{C}_{2} \mathrm{H}_{5} \mathrm{ONO}_{2}, \mathrm{PNP} 68 \%\right.$, etc. $)$. Other nitrogen compounds such as $\mathrm{HO}_{2} \mathrm{NO}_{2}, \mathrm{HNO}_{2}$, and $\mathrm{RO}_{2} \mathrm{NO}_{2}$ are supposedly effectively converted to $\mathrm{NO}$, whereas the conversion of $\mathrm{N}_{2} \mathrm{O}, \mathrm{HCN}, \mathrm{CH}_{3} \mathrm{CN}$ and $\mathrm{NH}_{3}$ are negligible $(<0.1 \%)$ at $400{ }^{\circ} \mathrm{C}[3]$.

The major problem with this type of converter corresponds to an important memory phenomenon which may persist several days, resulting from the active surface of the catalyzer. Furthermore, we can find a reduction in conversion efficacy, in particular after prolonged utilization in the presence of air highly polluted by $\mathrm{NO}_{y}$ and hydrocarbons. In addition, when functioning in normal mode, the molybdenum oxides forming $\mathrm{MoO}_{2}$ and $\mathrm{MoO}_{3}$ which can migrate into the flow tubes in powder form and increase the memory effects [3,4]. The analysers equiped with this type of converter have a limit of detection of about 300 ppt. This depends on the memory phenomenon as well as the conversion efficiency [3].

\section{Conversion on gold surface}

Fahey proposed in 1985 a reduction technique of $\mathrm{NO}_{y}$ into $\mathrm{NO}$, by catalysis on a gold surface comprised of temperatures between 300 and $350{ }^{\circ} \mathrm{C}$ [5]. This reduction is carried out in the presence of $\mathrm{CO}$ or $\mathrm{H}_{2}$ as the reducing agents. The addition of $\mathrm{CO}$ does not interfere with the measurement of NO. The CO is necessary for the reduction of $\mathrm{NO}_{y}$ and allows a lower detection limit by $10 \%$ [5]. The conversion of $\mathrm{NO}_{y}$ exceeds $98 \%$ for $\mathrm{NO}_{2}, \mathrm{HNO}_{3}, \mathrm{~N}_{2} \mathrm{O}_{5}, \mathrm{PAN}$ and PNP $(76 \%)$ [5,6]. The interferences due to the conversion of $\mathrm{NH}_{3}$ and $\mathrm{HCN}$ are negligible [6].

\section{Set-up of $\mathrm{NO}_{\mathrm{y}}$ converter}

The major problem observed during $\mathrm{NO}_{y}$ measurements correspond to the loss of nitric acid on the sampling line followed by a subsequent desorption. This adsorption of nitric acid, which constitutes a major type of $\mathrm{NO}_{y}$, is carried out on all surfaces. It is preferable to withdraw all sampling lines and to place the gold converter directly in contact with the air samples to be analyzed.

In the case of airborne measurements, we should also prevent any leaks occurring at altitudes. The tightness, on a gold tube, is impossible to verify due to the large malleability of this metal and of its thermal expansion. We have therefore, decided for a stainless steel tube $(500 \mathrm{~mm}$ in length, $60 \mathrm{~mm}$ internal diameter) whose internal surfaces are coated with $10 \mu \mathrm{m}$ of gold (Degussa ${ }^{\circledR}$ ). The conversion is carried-out on a gold tube which is introduced in the stainless steel tube.

The mixture is heated by a line-cord resistor. The regulation of the temperature is ensured by a regulator (TC Model Rex F400).

\section{Converter characteristics}

The $\mathrm{NO}_{2}$, PAN and nitric acid are, along with NO, the principle compounds consisting $\mathrm{NO}_{y}$. We have therefore tested the conversion efficiency of these compounds.

\section{Conversion efficiency in function of oven temperature}

The conversion temperatures tested range between $50{ }^{\circ} \mathrm{C}$ and $400{ }^{\circ} \mathrm{C}$. The conversion is done with a gas flow leading to a mixing ratio of $0.3 \%$ [5]. Finally, the flow is 3 to 3.5 $\mathrm{L} / \mathrm{min}$ permitting concentrations of $\mathrm{NO}_{y}$ between 50 and 80 ppb.

\section{Conversion of nitrogen dioxide}

The test performed in the presence of a gas reductor show that the conversion is complete for temperatures exceeding $200{ }^{\circ} \mathrm{C}$ (Fig. 2).

Whatever the conversion temperature, the signal given by the $\mathrm{NO}_{x}$ (channel) remains constant. The conversion of $\mathrm{NO}_{2}$ doesn't produce a loss or production of supplementary $\mathrm{NO}_{y}$. Few results have been published concerning the conversion without a reducing agent. In order to clarify the importance of a reducing agent. in the reduction process, reduction tests of $\mathrm{NO}_{2}$ were performed excluding $\mathrm{CO}$. Our results show two temperature domains. (Fig. 3). As a result, for temperatures exceeding $25{ }^{\circ} \mathrm{C}$ the conversion increases and becomes complete at $260{ }^{\circ} \mathrm{C}$ (conversion efficiency at 98.5\%) Then for temperatures exceeding $260{ }^{\circ} \mathrm{C}$, the conversion loses its efficiency: not more than $41 \%$ efficacy at $400{ }^{\circ} \mathrm{C}$. This phenomen will be explained below. Morever, the concentration levels detected on the $\mathrm{NO}_{x}$ channel remain constant during

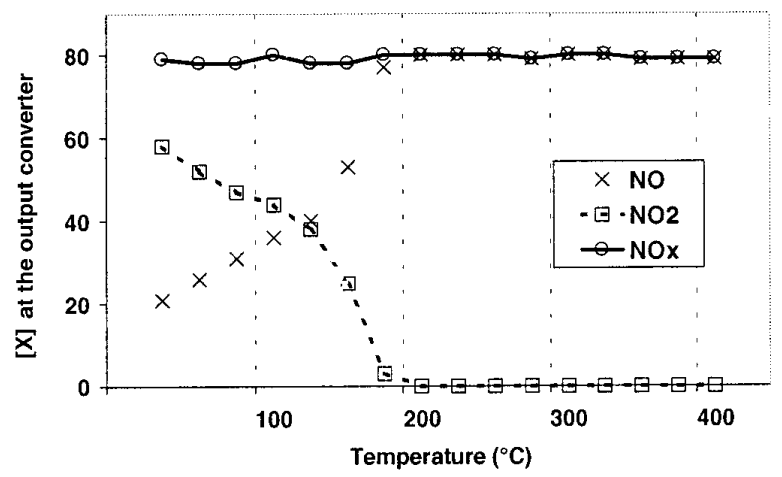

Figure 2. $\mathrm{NO}_{2}$ conversion with a reducing gas. 


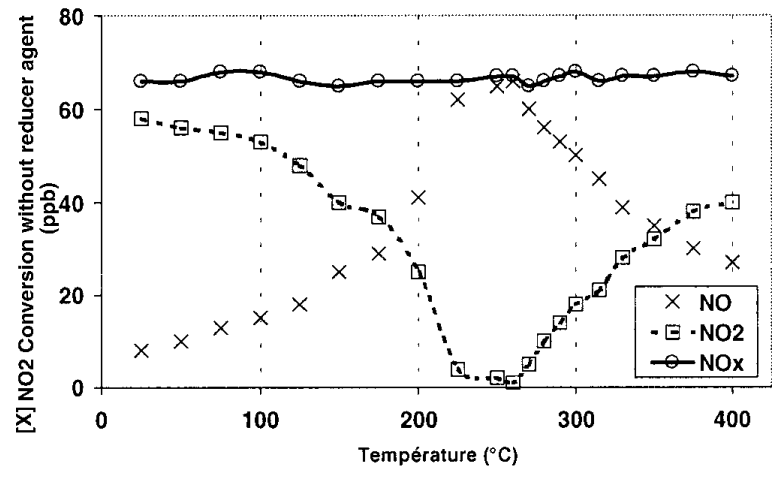

Figure 3. $\mathrm{NO}_{2}$ conversion without a reducing gas.

the entire temperature range. There is therefore no loss or formation of other nitrogen species detectable.

\section{Conversion of nitrogen monoxide}

The results of nitrogen dioxide conversion without a reducing agent have led us to take a closer look at the test results using the oven with NO.

When the tests are carried-out in the presence of $\mathrm{CO}$ at $0.3 \%$, only $\mathrm{NO}$ is detected throughout the entire temperature range studied. There is therefore, no influence on the conversion conditions on the nitrogen monoxide. On the other hand, in the absence of a reducing agent, we find a decrease of NO signal beyond $250{ }^{\circ} \mathrm{C}$, which is compensated by an augmentation of the signal detected on the $\mathrm{NO}_{2}$ channel. This interference is increased between 250 and $400{ }^{\circ} \mathrm{C}$ (Fig. 4).

The $\mathrm{NO}_{x}$ signal remains constant during the entire test. We can therefore conclude the presence of a more complex oxidation mechanism for $\mathrm{NO}$, starting at $250{ }^{\circ} \mathrm{C}$ and leading to a reactive nitrogen species (i.e. included in $\mathrm{NO}_{y}$ ) because detectable by a $\mathrm{NO}_{x}$ analyzer.

This test allows an understanding of the decrease in efficiency of the $\mathrm{NO}_{2}$ conversion at high temperatures. For temperatures exceeding $250{ }^{\circ} \mathrm{C}$, an oxidation mechanism of $\mathrm{NO}$ enters in competition with the process of thermal conversion.

The results we have obtained show the necessity of the presence of a reducing gas so that the effectiveness of the conversion stays maximal, but also to prevent interference reactions with nitrogen monoxide at high temperatures.

\section{Conversion of nitric acid}

We were able to test the conversion efficiency of the gold oven for nitric acids thank to a $\mathrm{HNO}_{3}$ generator developed in the laboratory (permeation tube) [7]. In the presence of $\mathrm{CO}$, the conversion of nitric acid to $\mathrm{NO}$ is completed from at $200{ }^{\circ} \mathrm{C}$ (Fig. 5).

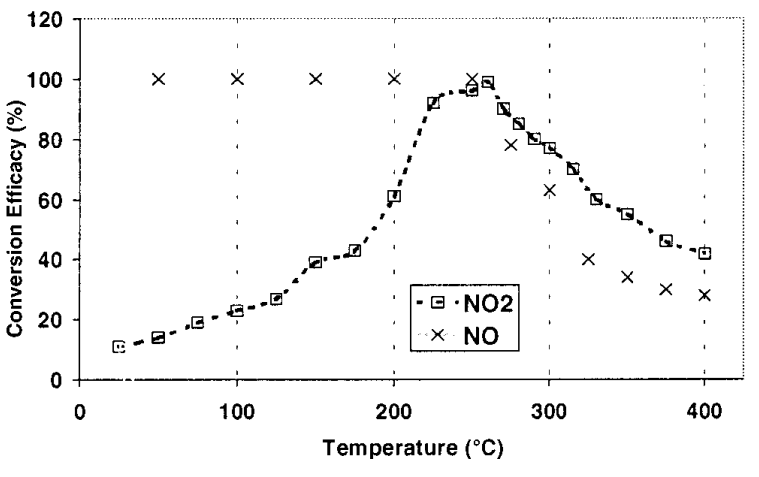

Figure 4. $\mathrm{NO}$ and $\mathrm{NO}_{2}$ conversion efficiency without $\mathrm{CO}$.

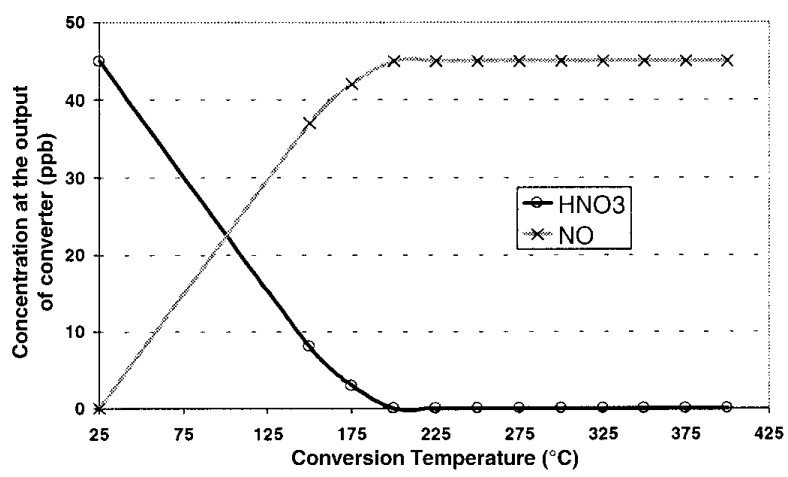

Figure 5. Nitric acid conversion.

\section{Conversion of PAN}

The peroxyacetyl nitrate, PAN, is one of the important constituents of $\mathrm{NO}_{y}$. It's major sink corresponds to it's thermal decomposition. After decomposition, the peroxyacetyl radical reacts either with $\mathrm{NO}_{2}$ to give back PAN or with $\mathrm{NO}$ to disappear definitely. The half-life of PAN is therefore dependant upon the $\mathrm{NO} / \mathrm{NO}_{2}$ ratio. The calculation of the half-life of PAN shows that at temperatures exceeding $300{ }^{\circ} \mathrm{C}$ the thermal decomposition of PAN is almost instantaneous (Tab. I).

For this reason, we have not performed conversion efficiency laboratory study for this species.

\section{Conversion efficiency in function of air flow passing through the oven}

In order to simulate the conditions produced during airborne measurements, the $\mathrm{NO}_{2}$ conversion efficiency has been tested with samples flows ranging from 1.45 to $13.55 \mathrm{~L} / \mathrm{min}$. Experiment with various flows allows us to vary the residence time of the gas in the oven and the contact time with the gold tube. This experiment alloweed us to make 3 justifications:

a) The conversion efficiency remains maximal throughout the series of flows experimented. 
Table I. PAN half time life(s) as a function of the $\mathrm{NO} / \mathrm{NO}_{2}$ ratio.

\begin{tabular}{lccccc}
\hline \multicolumn{5}{c}{ Temperatures $(K)$} \\
NO/NO & 273 & 373 & 473 & 573 & 623 \\
\hline 10 & $1.3 \mathrm{E} 5$ & $2.2 \mathrm{E}-1$ & $1.0 \mathrm{E}-4$ & $7.0 \mathrm{E}-7$ & $1.0 \mathrm{E}-7$ \\
5 & $1.4 \mathrm{E} 5$ & $2.4 \mathrm{E}-1$ & $1.1 \mathrm{E}-4$ & $7.4 \mathrm{E}-7$ & $1.1 \mathrm{E}-7$ \\
1 & $2.1 \mathrm{E} 5$ & $3.5 \mathrm{E}-1$ & $1.6 \mathrm{E}-4$ & $1.1 \mathrm{E}-6$ & $1.6 \mathrm{E}-7$ \\
0.5 & $2.9 \mathrm{E} 5$ & $4.9 \mathrm{E}-1$ & $2.3 \mathrm{E}-4$ & $1.5 \mathrm{E}-6$ & $2.3 \mathrm{E}-7$ \\
0.1 & $9.5 \mathrm{E} 5$ & $1.6 \mathrm{E} 0$ & $7.4 \mathrm{E}-4$ & $5.0 \mathrm{E}-6$ & $7.5 \mathrm{E}-7$ \\
\hline
\end{tabular}

b) The oven and $\mathrm{NO}_{x}$ analyzer respond instantly to variations $\mathrm{NO}_{2}$ and $\mathrm{HNO}_{3}$ concentrations.

c) We have shown a good correspondence between the concentrations, after dilution, of $\mathrm{NO}_{2}$ calculated and measured by the analyzer.

\section{Conversion efficiency and mixture ratio of reducing gas}

Most of the research teams which use the $\mathrm{NO}_{y}$ conversion technique on gold, carry-out the conversion with a yield of $\mathrm{CO}$ mix of $0.3 \%$. The concentrations of $\mathrm{NO}_{y}$ in the atmosphere rarely exceed several $\mathrm{ppb}$, the carbon monoxide therefore is found in large excess at the time of conversion. We have tested the efficiency of $\mathrm{NO}_{2}$ conversion using various concentrations of reducing gas. By the way, we wanted to know what would be the effect of varying the reducing gas mixing ratio on the conversion efficiency. The yield mix of $\mathrm{CO}$ tested are comprised between $0.42 \%$ and $0.0077 \%$ (i.e. $77 \mathrm{ppm}$ ). The results show (Fig. 6) that the conversion efficiency is $100 \%$ for mixing ratios higher than $42 \%$ (420 ppm). However, the conversion efficiency remains higher than $94 \%$ for concentration of $77 \mathrm{ppm}$. We can emphasize that it is important to carry-out the conversion in the presence of a large excess of $\mathrm{CO}$ and that the weak variations of it's mixing ratio are acceptable.

\section{Memory effect}

The oven converter presents a large surface for exchange. Some species adsorb more or less strongly on the surface living and are alternately re-ejected, giving a memory signal interference.

Nitrogen dioxide case: For temperatures higher than $200{ }^{\circ} \mathrm{C}$ the converter does not show memory effects. In fact, we have seen that the phenomenon of $\mathrm{NO}_{2}$ fixation in the oven become negligible at a high temperature.

Nitric acid case: The nitric acid is adsorbed by the oven walls whatever the temperature. In the presence of a reducing gas the memory effect given by the oven is 3 to $5 \mathrm{ppb}$ over a $15 \mathrm{~min}$ period, at $350{ }^{\circ} \mathrm{C}$ (the initial concentration being $40 \mathrm{ppb}$ ). This memory effect lasts $20 \mathrm{~min}$ at a temperature of $300{ }^{\circ} \mathrm{C}$. On the other hand, in the absence of

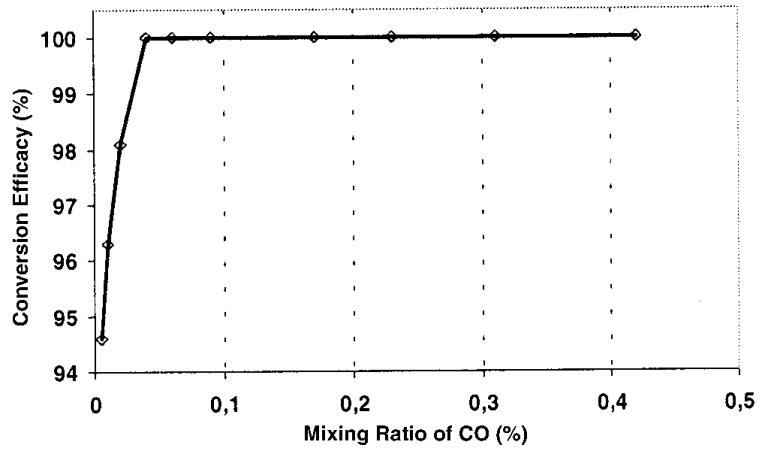

Figure 6. Variation of conversion efficiency with the concentration of the reducing gas.

$\mathrm{CO}$, the oven does not give any detectable memory effects. We can then assume that the action of the $\mathrm{CO}$ is to reduce the nitric acid molecules which are adsorbed on the oven walls and that the temperature alone are not sufficient enough to desorb the nitric acid molecules.

\section{Interest of $\mathrm{NO}_{y}$ measurement}

In order to qualitatively and quantitatively understand the processes that induce ozone production, it is necessary to answer the following questions:

- Is the air mass still able to produce ozone?

- If so, with what degree of efficiency?

- What is the precursor $\left(\mathrm{NO}_{x}\right.$ or $\left.\mathrm{COV}\right)$ which limits ozone production?

The answer to all of these questions requires the $\mathrm{NO}_{y}$ measurement.

\section{Is the air mass still able to produce ozone?}

Nitrogen oxides may be use as photochemical age indicators of an air mass. The $\mathrm{NO}_{z} / \mathrm{NO}_{y}$ ratio gives an estimation of photochemical age relative to the nitrogen oxides content in the air mass [8]. The proportion of $\mathrm{NO}_{z} / \mathrm{NO}_{y}$ indicates the percentage of oxidation products of $\mathrm{NO}_{x}$ (i.e. $\mathrm{NO}_{z}$ ) in $\mathrm{NO}_{y}$ and will evolve with photochemistry. In areas close to the source, the $\mathrm{NO}_{y}$ are essentially constituted of $\mathrm{NO}_{x}$. The photochemical age will be then close to $0 \%$. The $\mathrm{NO}_{x}$ will participate in the photochemical cycles of ozone production, as long as they will not be oxidized in the form of $\mathrm{NO}_{z}$. Also, as long as the air mass is photochemically active, the proportion of $\mathrm{NO}_{x}$ will decrease whereas that of $\mathrm{NO}_{z}$ will increase. The photochemical age will then have a tendency to augment. If the air mass does not receive supplementary contributions of $\mathrm{NO}_{x}$ by emissions, the photochemical age will then tends towards $100 \%$. Knowing the photochemical 
age therefore allows us to evaluate the potential of the air mass to produce ozone.

The relation between ozone production $\left(\mathrm{PO}_{3}\right)$ and the photochemical age of an air mass allows us to evaluate the ozone production potential. $\mathrm{PO}_{3}$ corresponds to the quantity of ozone formed and can be determined by differences between the ozone concentration measured in the air mass and the ozone background level. We will see latter how this background level can be determined. In order to eliminate the influence of various sources of nitrogen precursors we have normalized the ozone production by $\mathrm{NO}_{y}$ and studied the relation $\mathrm{P}\left[\mathrm{O}_{3}\right] /\left[\mathrm{NO}_{y}\right]=f$ (photochemical age) [7].

The relation met between photochemically young and old air masses indicate that ozone production does not developed in a constant and linear manner during it's aging. In the case of a photochemically young air mass we can see, in figure 7 , an increase of the ozone production potential with the augmentation of photochemical age. This indicates that in this air mass the number of ozone molecules produced per molecule of NO emitted, increases with the photochemical aging process. For example, when the air mass has a $10 \%$ photochemical age $\left(10 \% \mathrm{NO}_{x}, 90 \% \mathrm{NO}_{z}\right)$, it's about 2 molecules of ozone which have been produced for each NO molecule emitted. Also, at 50\% photochemical age, this quantity is increased to 6 molecules. On the contrary, in a photochemically aged air mass $(>70 \%)$ we find a limitation of the ozone production potential, although the photochemical age varies between $70 \%$ and $90 \%$. Therefore exists, in this case, a balance between the ozone production and its destruction process.

\section{What is the ozone production efficiency?}

The association of $\mathrm{NO}_{z}$ and ozone data allows us to evaluate the ozone production efficiency (OPE) relative to the nitrogen oxides. This OPE is determined by studying the ratio $\mathrm{O}_{3} / \mathrm{NO}_{z}$ [9]. Indeed, the $\mathrm{NO}_{x}$ not yet having exited the photochemical cycles of ozone production, must not be taken into account when considering the nitrogen oxide data. We must therefore use only the $\mathrm{NO}_{z}$ data. Evaluation OPE allows us to judge the "quality" of ozone production. It allows the evaluation of the number of ozone molecules produced per $\mathrm{NO}_{x}$ molecule emitted.

The OPE value depends on the following criteria [7].

- Ambiant concentrations of ozone, nitrogen oxides, and NMHC.

- Ratio of $\mathrm{NO}_{x} / \mathrm{VOC}$ which will drive the ozone production system.

- Speciation of various hydrocarbons constituting NMHC.

- The process of loss by deposition.

- The night time chemistry.

Determination of the OPE value comes from the graphic representation showing the correlation between ozone and $\mathrm{NO}_{z}$ (Fig. 8). From this linear regression, we can conclude that:

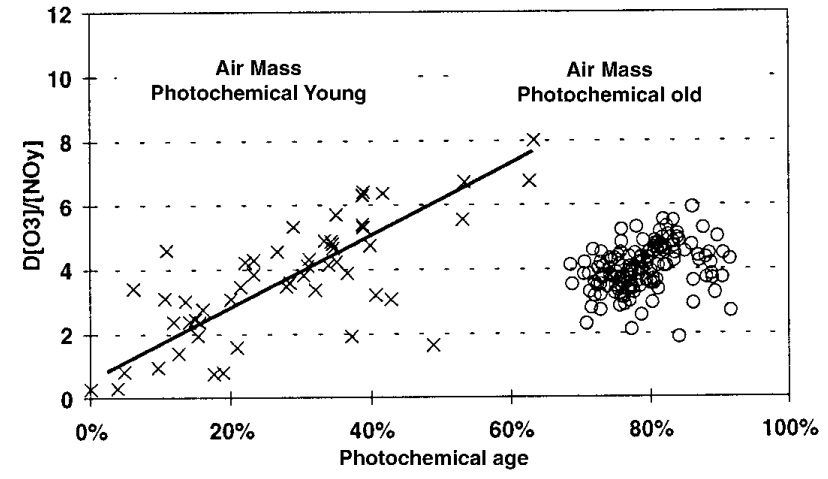

Figure 7. Evolution of ozone production potential with photochemical age.

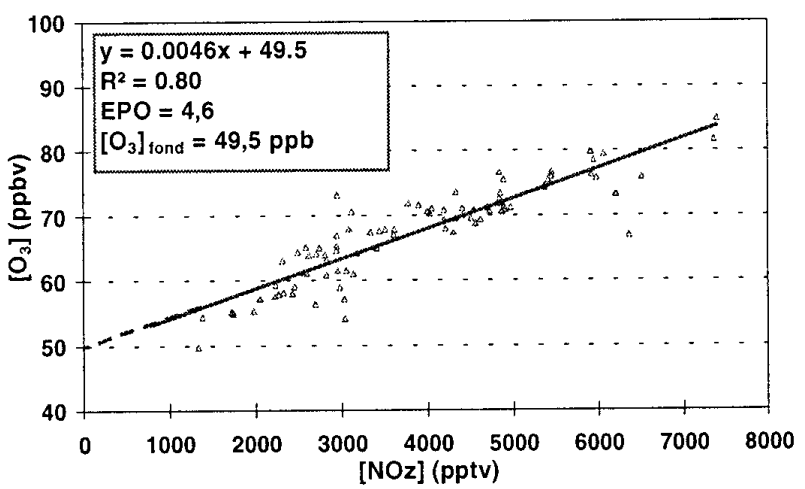

Figure 8. $\mathrm{O}_{3}$ and $\mathrm{NO}_{z}$ correlation.

- The slope of the $\mathrm{O}_{3} / \mathrm{NO}_{z}$, regression corresponds to OPE. In the example presented in figure 8, the slope is 0.0046 , implying an OPE of 4.6. In the air mass, there is therefore 4.6 ozone molecules produced per $\mathrm{NO}_{z}$ molecule produced, or per $\mathrm{NO}_{x}$ molecule oxidized.

- The ordinate of the linear regression corresponds to the level of ozone in the air mass when the $\mathrm{NO}_{z}$ level is 0 , that is to say when the photochemical aging process has not yet affected the air mass. This value corresponds to the ozone background level.

The OPE values generally measured range between 4 and 14 in rural zones $[9,10]$ however it's necessary to consider these values as high limits taking into account that the deposition processes must strongly increase the OPE values [11]. In tropical areas, the OPE varies between 4.6 and 7.2 in photochemically aged air masses, isolated from ground and therefore from deposition processes, and between 6.3 and 14.8 in the planetary boundary layer [7].

\section{What are the precursors $\left(\mathrm{NO}_{x}\right.$ or VOC) which limit ozone production?}

A detailed study of ozone formation and the photooxidants is necessary before planning the most effective reduction 
strategy. In fact, if each one of the two families of precursors $\left(\mathrm{NO}_{x}\right.$ and $\left.\mathrm{COV}\right)$ is susceptible to allow a reduction of ozone production $\left(\mathrm{PO}_{3}\right)$ this effect will be different depending on the type of chemical production process. If a precursor limits the production, a reduction of its emissions will effectively reduce ozone production whereas a reduction of the emission of the other precursor will have a very limited effect.

It has been shown [12] that, for $\mathrm{NO}_{x}$ concentrations inferior to $2 \mathrm{ppb}$ (low $\mathrm{NO}_{x}$ ), $\mathrm{PO}_{3}$ is almost proportional to the concentration of NO and practically independent of the VOC concentration. The ozone production is therefore dependent upon $\mathrm{NO}_{x}$. The photochemical production of ozone increases rapidly versus $\mathrm{NO}_{x}$ concentrations. In this case values up to $10 \mathrm{ppb} / \mathrm{hr}$ can be obtained. On the other hand, for $\mathrm{NO}_{x}$ concentration higher than $5 \mathrm{ppb}$ (high $\mathrm{NO}_{x}$ ), $\mathrm{PO}_{3}$ increases with an augmentation of VOC and decrease with an augmentation of $\mathrm{NO}_{x}$. The ozone production is therefore dependent upon VOC. The photochemical production of ozone therefore varies between 1 and $2 \mathrm{ppb} / \mathrm{hr}$ according to the hydrocarbon concentrations. Between these 2 cases is found a transition zone.

Air masses over rural zones generally exhibit weak concentrations of $\mathrm{NO}_{x}$ (low $\mathrm{NO}_{x}$ ) and are therefore, most often, in a state sensitive to $\mathrm{NO}_{x}$ during the summer period. Over urban zones the $\mathrm{NO}_{x}$ and $\mathrm{VOC}$ emissions can tip the system towards an ozone production sensitive to VOC (high $\mathrm{NO}_{x}$ ). In moving away from urban zones, the air mass travels above regions of weak $\mathrm{NO}_{x}$ emissions. Dilution in the air mass and chemical reactions reduces precursor concentrations. We are then in a transition zone. Thereafter, new biogenic emissions of VOC bring the chemical mechanisms back to a $\mathrm{NO}_{x}$ sensitive regime (low $\mathrm{NO}_{x}$ ). It is consequently important to know the temporal evolution and spatial extension of different chemical regimes (low $\mathrm{NO}_{x}$-high $\mathrm{NO}_{x}$-transition) as well as the corresponding oxidant production in order to improve the reduction strategies.

The sensibility of ozone production in respect to $\mathrm{NO}_{x}$ and VOC concentrations is important in estimating the impact of emission reduction strategies, or even to study the variability of photochemical processes in the intermediate region between the source and regional areas. Sillman [13] proposed in 1995 the use of indicators of this sensibility instead of the 3D model which may sometimes give important errors associated with transport and chemistry. Amongst those indicators, there are $\mathrm{NO}_{y}, \mathrm{O}_{3} / \quad\left(\mathrm{NO}_{y}-\mathrm{NO}_{x}\right), \mathrm{HCHO} / \mathrm{NO}_{y}$, $\mathrm{H}_{2} \mathrm{O}_{2} / \mathrm{HNO}_{3}$.

\section{Examples of $\mathrm{NO}_{y}$ airborne measurements}

As a preliminary example, we present in figure 9, a $2 \mathrm{D}$ representation of $\mathrm{NO}_{y}$ concentrations obtained during the May 1998 PIPAPO campaign. The urban plume is clearly visible on this curve with concentrations reaching $26 \mathrm{ppb}$ downwind Milan whereas the lowest values during this same period

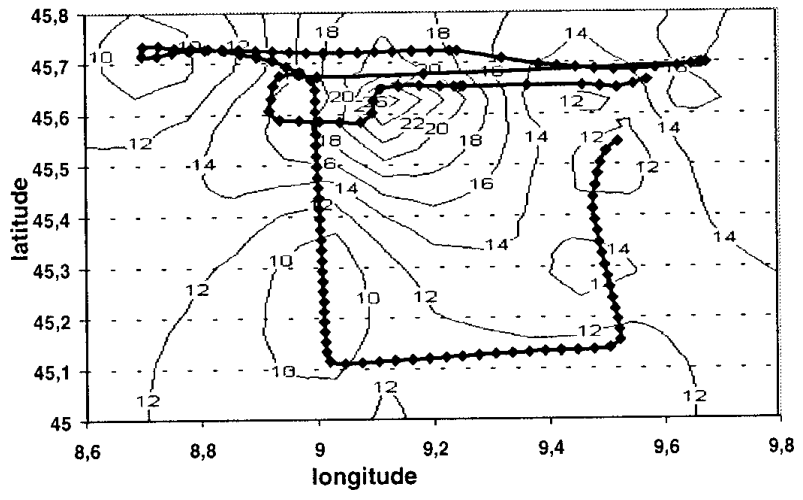

Figure 9. Iso-concentration (ppb) lines for $\mathrm{NO}_{y}$ in the Milan area. The aircraft trajectory is presented with bold dots.

range between $10-12 \mathrm{ppb}$. The treatment and interpretation of the data collected during this PIPAPO campaign will be the object of a future publication.

\section{Conclusions}

The nitrogen compounds play a key role in the tropospheric ozone production process. The individual airborne measurement of the different constituents is difficult to determine. However, their global measurement is easier to obtain but requires an adapted converter. The major problem in measuring $\mathrm{NO}_{y}$ is due to the loss of nitric acid in the sample line. The nitric acid absorption occurs on all surfaces. As a result, it is best to cancel all sampling lines and to place the converter directly in contact with the air sample to be analyzed. The tests carried-out in the laboratory allowed us to determine the principle characteristics of $\mathrm{NO}_{y}$ 's conversion.

The presence of the reducing gas such as $\mathrm{CO}$ is indispensable in the conversion process. In addition, it prevents the appearance of $\mathrm{NO}$ oxidation interference reactions between 250 and $400{ }^{\circ} \mathrm{C}$.

CO mixing ratios between 0.42 and $0.042 \%$ allow a total conversion of $\mathrm{NO}_{y}$.

Flow rate contained between 1.45 and $13.5 \mathrm{~L} / \mathrm{min}$ do not lower the conversion efficiency.

Between 250 and $400{ }^{\circ} \mathrm{C}$ the conversion efficiency of $\mathrm{NO}_{2}$ and $\mathrm{HNO}_{3}$ are optimal. Therefore, if we would like to minimize the adsorption and desorption problem of nitric acid on the oven walls, it is preferable to carry out the conversion between 350 and $400{ }^{\circ} \mathrm{C}$.

The gold oven converter enables a complete conversion of $\mathrm{NO}_{y}$ up to concentrations reaching $80 \mathrm{ppb}$. The amount of $\mathrm{NO}_{y}$, coupled with $\mathrm{NO}$ and $\mathrm{NO}_{z}$ allows a quantitative and qualitative study of the processes resulting in ozone 
production. It enables, in particular, the determination of the ozone production potential of the air mass, the effectiveness with which the ozone is produced and the chemical process of ozone production. This type of detailed study of ozone and photooxydant formation is necessary before establishing the most effective reduction strategy.

\section{References}

1. Marenco, A.; Gouget, H.; Nédélec, P.; Pagès, J. P.; Karcher, F. J. Geophys. Res. 1994, 99, 16617-16632.

2. L'Ozone Troposphérique, Compte Rendu de l'Académie des Sciences n³0, Technique et Documentation Ed., Paris, 1994.

3. Dickerson, R. R. Atm. Env. 1984, 18(12), 2585-2593.

4. Fehsenfeld, F. C.; Dickerson, R. R.; Hübler, G.; Murphy, P. C.; Luke, W. T.; Williams, E. J.; Eubank, C. S.; Fahey, D. W.; Nunnermacker, L. J.; Roberts, J. M.; Calvert, J. G.; Curran, C. M.; Delany, A. C.; Fried, A.; Gandrud, B. W.; Landford, A. O.; Norton, R. B.; Pickering, K. E.; Ridley, B. A. J. Geophys. Res. 1987, 92(D12), 14710-14722.

5. Fahey, D. W.; Eubank, C. S.; Hübler, G.; Fehsenfeld, F. C. J. Atm. Chem. 1985, 3, 435-468.
6. Fahey, D. W.; Hübler, G.; Parrish, D. D.; Williams, J. E.; Norton, R. B.; Ridley, B. A.; Singh, H. B.; Liu, S. C.; Fehsenfeld, F. C. J. Geophys. Res. 1986, 91(D9), 9781-9793.

7. Marion, T. Mesure aéroportées des oxydes d'azote : application à l'étude des processus de production d'ozone dans l'atmosphère tropicale. Thèse de Doctorat en Sciences, Université Paris 12, 1998.

8. Carroll, M. A.; Ridley, B. A.; Montzka, D. D.; Walega, J. G.; Norton, R. B.; Huebert, B. J.; Hübler, G.; Grahek, F. E. J. Geophys. Res. 1992, 97(D10), 10361-10374.

9. Trainer, M.; Parrish, D. D.; Buhr, M. P.; Norton, M. R. B.; Fehsenfeld, F. C.; Anlauf, K. G., Bottenheim, J. W.; Tang, Y. Z.; Wiebe, H. A.; Roberts, J. M.; Tanner, R. L.; Newman, L.; Bowersox, V. C.; Meagher, J. F.; Olszyna, K. J.; Rodgers, M. O.; Wang, T.; Berresheim, H.; Roychowdhury, U. K. 1993, J. Geophys. Res. 1998, D2, 2917-2925.

10. Olszyna, K. J.; Bailey, E. M.; Simonaitis, R.; Meagher, J. F. J. Geophys. Res. 1994, 99(D7), 14557-14563.

11. Trainer, M.; Ridley, B. A.; Buhr, M. P.; Kok, K.; Walega, J.; Hübler, G.; Parrish, D. D.; Fehsenfeld, F. C. J. Geophys. Res. 1995, 100(D9), 18823-18834.

12. Sillman, S.; Logan, J.A.; Wofsy, C.S. J. Geophys. Res. 1990, 95, 1837-1851.

13. Sillman S. J. Geophys. Res. 1995, 100(D7), 14175-14188. 